\section{Postharvest Response of Two Strawberry Cultivars to Foliar Application of $\mathrm{CaCl}_{2}$}

\author{
F. Chéour ${ }^{1}$, C. Willemot ${ }^{1,2}$, J. Arul ${ }^{1}$, J. Makhlouf ${ }^{1}$, and \\ Y. Desjardins ${ }^{3}$ \\ Département de Sciences et Technologie des Aliments, Université Laval, \\ Que., PQ G1K 7P4, Canada
}

Additional index words. Fragaria $\times$ ananassa, calcium, shelf life

Abstract. The objective of this study was to compare the effects of the foliar application of $\mathrm{CaCl}_{2}$ on the shelf life and $\mathrm{Ca}$ content of the fruit of the strawberry (Fragaria $x$ ananassa) cultivars Kent and Glooscap, which differ in fruit firmness. Calcium was applied repeatedly, 3 days, 3 and 6 days, or 3,6 , and 9 days before harvest at 0,10 , or $20 \mathrm{~kg}^{-1}$. Calcium treatment influenced amounts of free sugars and organic acids, color, texture, and disease development during storage in air at $4 \mathrm{C}$. Calcium application had more effect on the fruit of the softer 'Glooscap', which contained relatively low levels of $\mathrm{Ca}$ at the time of treatment. Calcium content of the fruit appeared to depend mainly on the ability of the plant to accumulate and distribute $\mathrm{Ca}$.

Delay of strawberry ripening and mold development by $\mathrm{Ca}$ treatment has been demonstrated (Chéour et al., 1990; Eaves and Leefe, 1962). Foliar application of $\mathrm{CaCl}_{2}$ on strawberry plants a few days before harvest increased fruit $\mathrm{Ca}$ content and influenced several postharvest senescence changes involving free sugar, organic acid, and anthocyanin contents and texture and electrical conductivity (Chéour et al., 1990).

Calcium application usually leads to an increase in apoplastic $\mathrm{Ca}$ concentration (Poovaiah, 1979) that may affect the structure and functions of cell walls and membranes and certain aspects of cell metabolism (Glenn et al., 1988), and delay leaf senescence (Poovaiah and Leopold, 1973) and fruit ripening (Paliyath et al., 1984; Richardson and Al-Alani, 1982; Tingwa and Young, 1974).

The present study compared the effects of foliar application of $\mathrm{CaCl}_{2}$ on fruit $\mathrm{Ca}$ content, fruit ripening, and susceptibility to mold development of two strawberry cultivars differing in firmness.

The Junebearing strawberry cultivars Kent, known for the firmness of the fruit, and

Received for publication 21 May 1990. Centre de Recherches et de Développement sur les Aliments, publication no. 142. The help of Sharon E. Bratt, Guylaine Trachy, and Monique Lacroix is gratefully acknowledged. This research was supported by the Conseil des Recherches en Pêches et Agro-alimentaire du Québec and the Natural Sciences and Engineering Research Council of Canada. The cost of publishing this paper was defrayed in part by the payment of page charges. Under postal regulations, this paper therefore must be hereby marked advertisement solely to indicate this fact.

${ }^{1}$ Département de Sciences et Technologie des Aliments, Université Laval.

${ }^{2}$ Centre de Recherches et de Développement sur les Aliments, Agriculture Canada, Saint-Hyacinthe.

${ }^{3}$ Département de Phytologie, Université Laval.
Glooscap, known for its softness, were selected. Calcium was applied over two consecutive years on different one-year-old strawberry fields by foliar application 3 to 9 days before harvest. Plants were grown on a Saint-Nicolas series sandy loam in matted rows with $1 \mathrm{~m}$ between rows, $60 \mathrm{~cm}$ on the row, and $2 \mathrm{~m}$ between plots. Plants from both cultivars were treated repeatedly with $\mathrm{CaCl}_{2}$, one, two, or three times, i.e., 3, 3 and 6 , or 3,6 , and 9 days before harvest, at a rate of 0,10 , or $20 \mathrm{~kg} \cdot \mathrm{ha}^{-1}$ by runs at a rate of $5 \mathrm{~kg} \cdot \mathrm{ha}^{-1}$, when the primary fruit were pink. At harvest, one-fourth to one-half pink secondary fruits were picked. 'Glooscap' ripened 2 days after 'Kent'. Fertilization was carried out as recommended by the Québec Dept. of Agriculture (CPVQ, 1982). time of treatment. berries at various rates and times of $\mathrm{CaCl}_{2}$ application.
Ripening was assessed by measuring firmness, color, free sugar and organic acid contents, and by visual rating of disease development.

Immediately after harvest, the strawberries were precooled and selected for uniformity of size, color (one-fourth to one-half red) and lack of injury. The fruits were stored at $4 \mathrm{C}$ for 23 days in 26-liter polyethylene containers under a 15 to 20 liter $\cdot \mathrm{h}^{-1}$ almostwater-saturated air stream. Air composition was checked daily by gas chromatography (Model 29; Fisher-Hamilton Gas Partitioner, Ottawa, Ont.), to ascertain that the air stream was sufficient to avoid $\mathrm{CO}_{2}$ accumulation.

Soil-exchangeable $\mathrm{Ca}$ was determined by the Mehlich 3 method (Mehlich, 1984). Fruit and leaves were washed with distilled water, and $\mathrm{Ca}$ was measured by atomic absorption spectrophotometry (Gaines and Mitchel, 1979). Older, dark-green leaves from the base of the plants and green or pink fruit samples were dried at $70 \mathrm{C}$ and digested with nitric and perchloric acid.

Free sugars were determined by refractometry (Bausch and Lomb optical series YB 3301; Bausch and Lomb, Rochester, N.Y.). The results were expressed as percent soluble solids. Organic acids and firmness were measured as described by Chéour et al. (1990). Color was determined as saturation index, $S=\sqrt{\left(a^{2}+b^{2}\right)}$ by the Hunter $L$, a, b method (Colorgard 1000; Pacific Scientific, Silver Spring, Md.). Visual rating of mold was according to a 10-point scale: 0 for a healthy fruit, 9 for a fruit completely covered with mold. Each determination was the average of a 40-strawberry sample.

Analysis of variance was done following a split-split-plot design (Snedecor and Cochran, 1957). Homogeneity of variance was tested by the standard Bartlett test (Anderson and McLean, 1974). Each treatment was

Table 1. Calcium content (percent dry matter, means of nine replicates 2 SD) of soil (exchangeable calcium), leaves, and fruits for control (no $\mathrm{CaCl}_{2}$ ) plots of 'Kent' and 'Glooscap' strawberries at

\begin{tabular}{lcccc}
\hline \hline Cultivars & Soil & Leaves & Green fruit & Pink fruit \\
\hline Kent & $33.1 \pm 0.4 \times 10^{-4}$ & $1.29 \pm 0.25$ & $0.37 \pm 0.06$ & $0.28 \pm 0.03$ \\
Glooscap & $33.3 \pm 0.5 \times 10^{-4}$ & $1.57 \pm 0.30$ & $0.35 \pm 0.07$ & $0.20 \pm 0.01$ \\
\hline
\end{tabular}

Table 2. Calcium content (percent dry matter) of leaves and fruits, for 'Kent' and 'Glooscap' straw-

\begin{tabular}{|c|c|c|c|}
\hline Rate $\left(\mathrm{kg} \cdot \mathrm{ha}^{-1}\right)$ & Leaves & Green fruit & Pink fruit \\
\hline \multicolumn{4}{|c|}{ Kent } \\
\hline 0 & 1.29 & 0.37 & 0.28 \\
\hline 10 & 1.92 & 0.44 & 0.34 \\
\hline 20 & 2.12 & 0.42 & 0.33 \\
\hline \multicolumn{4}{|l|}{ Significance } \\
\hline Treatment & 0.001 & NS & NS \\
\hline Linear & 0.001 & NS & NS \\
\hline \multicolumn{4}{|c|}{ Glooscap } \\
\hline 0 & 1.57 & 0.35 & 0.20 \\
\hline 10 & 2.25 & 0.38 & 0.35 \\
\hline 20 & 2.47 & 0.40 & 0.31 \\
\hline \multicolumn{4}{|l|}{ Significance } \\
\hline Treatment & 0.05 & 0.012 & 0.001 \\
\hline Linear & 0.03 & 0.003 & 0.001 \\
\hline \multicolumn{4}{|l|}{ Interaction } \\
\hline Cultivars $\times$ treatment & NS & 0.041 & 0.029 \\
\hline
\end{tabular}




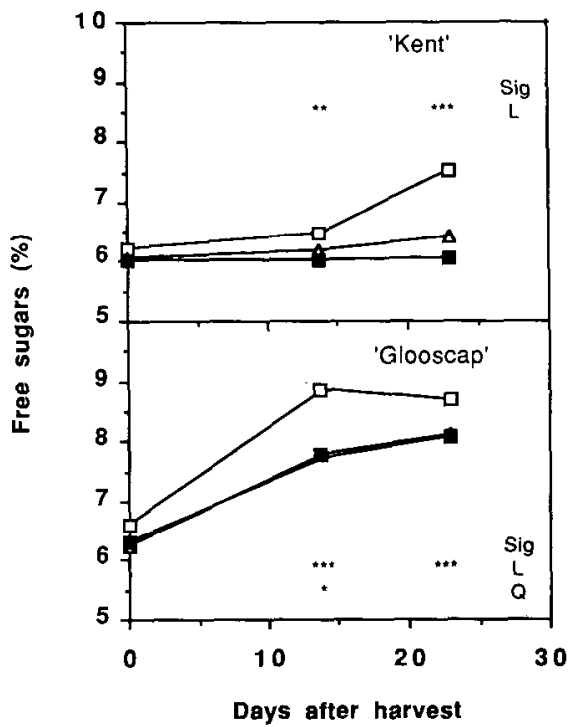

Fig. 1. Free sugar content (percent fresh weight) of 'Kent' and 'Glooscap' strawberries during storage at $4 \mathrm{C}$ after foliar $\mathrm{CaCl}_{2}$ application at 0 $(\square), 10(\Delta)$, and $20(\boldsymbol{\square}) \mathrm{kg} \cdot \mathrm{ha}^{-1}$. Where the effects of $\mathrm{Ca}$ treatment at each date of analysis are significant, degree of significance is indicated by $*(P<0.05), * *(P<0.01)$ or $* * *$ $(P<0.001)$.

replicated three times. Although the experiments were carried out over two consecutive years, the results were similar and only the results of the 2nd year are reported.

Calcium content of fruit and leaves at the time of treatment varied significantly between cultivars (Table 1). Calcium was apparently more evenly distributed in 'Kent', where relatively more $\mathrm{Ca}$ was located in the pink fruit than for 'Glooscap'. Foliar application of $\mathrm{CaCl}_{2}$ before harvest at the rate of $20 \mathrm{~kg} \cdot \mathrm{ha}^{-1}$ caused a greater relative increase in Ca content in the leaves in 'Kent' than in 'Glooscap' $(0.83 \%$ dry matter or $64 \%$ of the value at treatment vs. $0.9 \%$ dry matter or $35 \%$ ) (Table 2). However, the Ca content of the fruit increased more in 'Glooscap' than in 'Kent' $(0.1 \%$ dry matter or $55 \%$ vs. $0.05 \%$ or $18 \%$ ). Significant interaction was observed between cultivars and other treatments. Calcium content was higher in green than in pink fruit for both cultivars (Tables 1 and 2).

The concentration of free sugars progres-

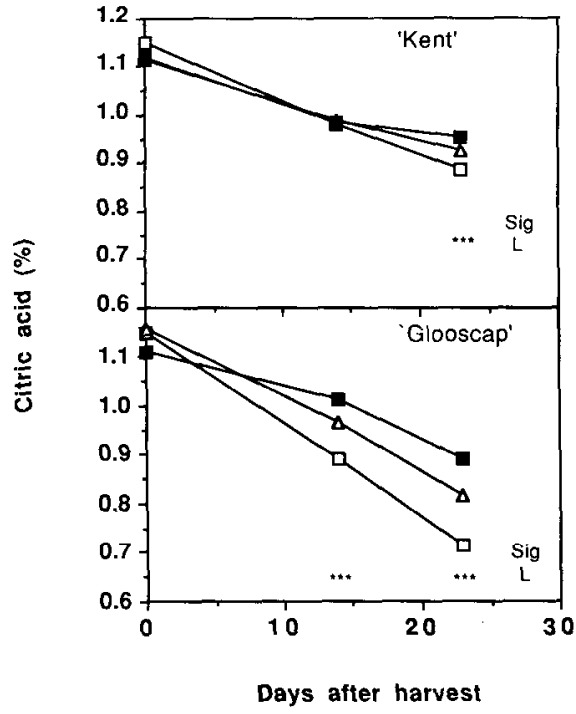

Fig. 2. Titratable acidity (citric acid, percent fresh weight) of 'Kent' sand 'Glooscap' strawberries during storage at $4 \mathrm{C}$ after foliar $\mathrm{CaCl}_{2}$ application. For symbols and significance, see Fig. 1.

sively increased with storage in both cultivars, but earlier for 'Glooscap' (Table 3, Fig. 1). This increase was only slightly delayed by $\mathrm{Ca}$ treatment for 'Kent', but quite markedly for 'Glooscap'.

The quantity of organic acids, expressed as citric acid, decreased in both cultivars during storage (Table 3, Fig. 2). Calcium treatment delayed this decrease, but more so with 'Glooscap'. The effect of Ca was observed after 14 days of storage for 'Glooscap' but only at the end of the storage period for 'Kent'.

The saturation index, which was initially much higher for 'Glooscap' than for 'Kent', increased for both cultivars (Table 3) to about the same level during storage. The effect of $\mathrm{Ca}$ was rather slight, but more pronounced in the case of 'Kent'.

With time of storage less force was required to compress the fruit (Table 3, Fig. $3)$. The decrease in firmness was delayed by $\mathrm{Ca}$ treatment. The effect of $\mathrm{Ca}$ treatment was observed at harvest and throughout the storage period for 'Glooscap', but only slightly at the end of the storage period for 'Kent'.

Mold developed sooner on 'Glooscap' than

Table 3. Significance level of differences, according to the source of variation for the attributes studied: free sugars (1), titratable acidity (2), saturation index (3), firmness (4), and mold development

\begin{tabular}{lccccc}
\hline \hline & \multicolumn{5}{c}{ Ripening attributes } \\
\cline { 2 - 6 } Source of variation & 1 & 2 & 3 & 4 & 5 \\
\hline Date & 0.002 & 0.012 & 0.001 & 0.001 & 0.001 \\
Application & NS & NS & 0.052 & 0.001 & 0.001 \\
Dose & 0.001 & 0.003 & 0.030 & 0.001 & 0.001 \\
$\quad$ Linear & 0.001 & 0.001 & 0.01 & 0.001 & 0.001 \\
Date $\times$ rate & 0.051 & 0.003 & NS & Ns & 0.001 \\
Cultivar & 0.001 & 0.003 & 0.001 & 0.001 & 0.001 \\
Cultivar $\times$ date & 0.001 & 0.003 & 0.001 & 0.001 & 0.001 \\
Cultivar $\times$ rate & NS & NS & 0.026 & 0.055 & 0.002 \\
Cultivar $\times$ rate $\times$ date & 0.011 & NS & 0.001 & 0.009 & 0.057 \\
Contrast & & & & & \\
$\quad$ Control vs. others & 0.001 & 0.001 & 0.001 & 0.001 & 0.001 \\
\hline
\end{tabular}

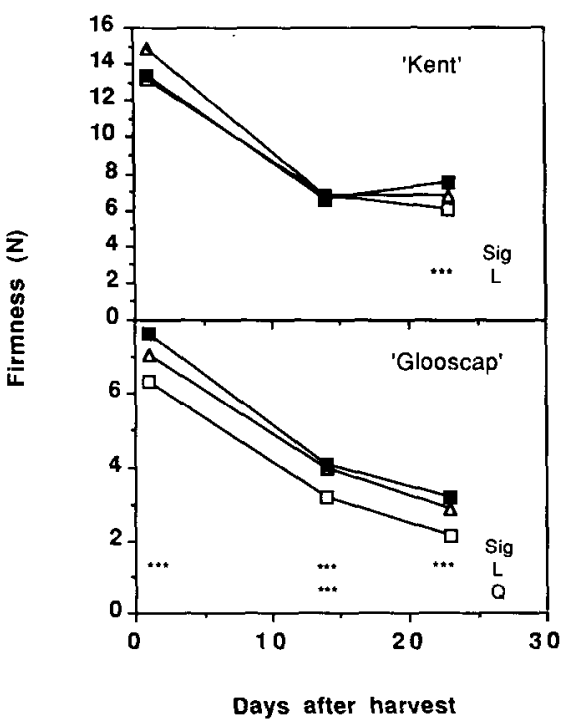

Fig. 3. Firmness of 'Kent' and 'Glooscap' strawberries during storage at $4 \mathrm{C}$ after $\mathrm{CaCl}$ application. For symbols and significance, see Fig. 1.

on 'Kent' (Fig. 4), and Ca delayed this development more on the former.

For all these maturity characteristics, except for organic acids, the cultivar $\times$ rate $\times$ date interaction was significant, which indicates that the cultivars did not respond in the same way to the Ca treatment (Table 3).

Our results confirm that foliar application of $\mathrm{CaCl}_{2}$ delays the fruit ripening of and mold development on strawberries (Chéour et al., 1990; Eaves and Leefe, 1962). The response to the $\mathrm{Ca}$ treatment was greater for 'Glooscap', which contained less Ca than 'Kent'. The effect of $\mathrm{Ca}$ is less pronounced in tissues that contain adequate amounts of $\mathrm{Ca}$ for maintaining cell integrity (Conway and Sams, 1987). The ability to accumulate and distribute Ca may vary with the cultivar and is influenced by various factors, e.g., temperature, relative humidity, levels of other minerals in the soil, age of the plant (Ferguson, 1984; Kirkby and Pilbeam,1984; Shear, 1975). The inability of the plants to accumulate and distribute $\mathrm{Ca}$ may partly explain why some cultivars are more prone to disorders and diseases (Hogue et al., 1983).

The greater $\mathrm{Ca}$ content of unripe fruit might be explained by solute influxvia the phloem, where $\mathrm{Ca}$ is known to be relatively immobile (Hanger, 1979). This influx increases with fruit development. Because of a lesser rate of cell division as the fruit mature, less binding sites for $\mathrm{Ca}$ are formed. Additionally, the volume : area ratio increases, which results in less transpiration per weight unit (Ferguson, 1984).

The decrease in saturation index of 'Glooscap' by the end of the storage may be indicative of the darker color of senescing fruit; molds may also secrete glycosidases, which degrade the anthocyanins with development of brown discoloration (Haard, 1988).

In conclusion, foliar application of $\mathrm{Ca}$ prolonged the shelf-life of strawberries, as 


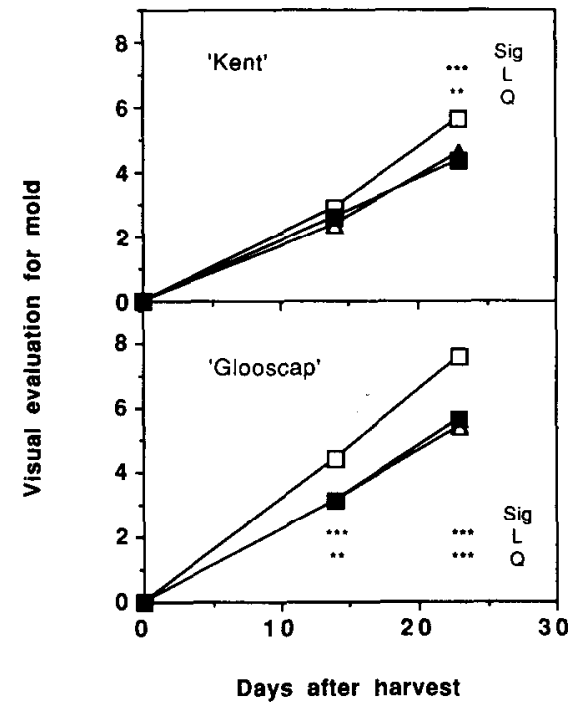

Fig. 4. Visual assessment of mold development on 'Kent' and 'Glooscap' strawberries during storage at $4 \mathrm{C}$ after foliar $\mathrm{CaCl}_{2}$ application. Mold presence was rated according to $0=$ healthy fruit, and $9=$ fruit completely covered with mold. Results are means of a 40-fruit sample. For symbols and significance, see Fig. 1.

measured by a delay in accumulation of sugars, decrease in organic acids, increase in color saturation index, and mold development. The response to the treatment varied with the cultivar and apparently depends on the $\mathrm{Ca}$ content of the fruit at the time of treatment and on the ability of the plant to accumulate and distribute $\mathrm{Ca}$.

\section{Literature Cited}

Anderson, V.L. and R.A. McLean. 1974. Design of experiments. Marcel Dekker, New York.

Chéour, F., C. Willemot, J. Arul, Y. Desjardins, J. Makhlouf, P.M. Charest, and A. Gosselin. 1990. Effects of foliar application of $\mathrm{CaCl}_{2}$ on postharvest strawberry ripening. J. Amer. Soc. Hort. Sci. 105:789-792.

CPVQ, Conseil des Productions Végétales du Quebec. 1982. Guide de la recommandation de la culture des petits fruits. Ministère de l'Agriculture, des Pêcheries et de l'Alimentation du Quebec.

Conway, W.S. and C.E. Sams. 1987. The effects of postharvest infiltration of calcium, magnesium or strontium on decay, firmness, respiration and ethylene production in apples. J. Amer. Soc. Hort. Sci. 112:300-303.

Eaves, C.A. and J.S. Leefe. 1962. Note on the influence of foliar sprays of calcium on the firmness of strawberries. Can. J. Plant Sci. 42:746-747.

Ferguson, LB. 1984. Calcium in plant senescence and fruit ripening. Plant Cell Environ. 7:447489.

Gaines, T.P. and G.A. Mitchell. 1979. Chemical methods for soil and plant analysis. Univ. of Georgia, Coastal Plain Expt. Sta. Agron. Hdbk. no. 1.

Glenn, G.M., A.S. Reddy, and B.W. Poovaiah. 1988. Effect of calcium on wall structure, protein phosphorylation and protein profile in senescing apples. Plant Cell Physiol. 29:565-572.

Haard, N.F. 1988. Characteristics of edible plant tissues, p. 857-911. In: O.R. Fennema (ed.). Food chemistry. 2nd ed. Marcel Dekker, New York.
Hanger, B.C. 1979. The movement of calcium in plants. Commun. Soil Sci. Plant Anal. 10:171193.

Hogue, E. J., G.H. Neilson, J.L. Mason, and B.G. Drought. 1983. The effect of different calcium levels on cation concentration in leaves and fruit of apple trees. Can. J. Plant Sci. 63:473-479.

Kirkby, E.A. and D.J. Pilbeam. 1984. Calcium as a plant nutrient. Plant Cell Environ. 7:397405.

Mehlich, A. 1984. Mehlich 3 soil test extractant: a modification of Mehlich 2 extractant. Commun. Soil Sci. Plant Anal. 15:1409-1416.

Paliyath, G., B.W. Poovaiah, G.R. Munske, and J.A. Magnuson. 1984. Membrane fluidity in senescing applies: Effects of temperature and calcium. Plant Cell Physiol. 25:1083-1087.

Poovaiah, B.W. 1979. Role of calcium in ripening and senescence. Commun. Soil Sci. Plant Anal. 10:83-101.

Poovaiah, B.W. and A.C. Leopold. 1973. Deferral of leaf senescence with calcium. Plant Physiol. 52:236-239.

Richardson, D.G. and A.M. Al-Alani. 1982. Calcium and nitrogen effects on d'Anjou pear fruit respiration and ethylene evolution. Acta Hort. 124:195-201.

Shear, C.B. 1975. Calcium-related disorders of fruits and vegetables. HortScience 10:361-365.

Snedecor, G.W. and W.G. Cochran. 1957. Statistical methods. 6th ed. Iowa State Univ. Press.

Tingwa, P.O. and R.E. Young. 1974. The effect of calcium on the ripening of avacado (Persea americana Mill.) fruits. J. Amer. Soc. Hort. Sci. 99:540-542. 